\title{
A DITADURA MILITAR NO DISCURSO MIDIÁTICO: UMA ABORDAGEM DISCURSIVA NA EDUCAÇÃO DE JOVENS E ADULTOS
}

\author{
Pedro Luís Fagundes do Amaral ${ }^{1}$ \\ Carolina Fernandes ${ }^{2}$
}

Resumo: Este artigo trata-se de uma pesquisa teórico-prática aplicada na Educação de Jovens e Adultos sobre o tema da ditadura militar no discurso midiático. Analisa-se, neste trabalho, a prática de leitura desenvolvida em sala de aula a partir da perspectiva teórica da Análise de Discurso, observando os movimentos de sentido nos gestos de interpretação dos alunos a partir dos conceitos de paráfrase e polissemia. Ao criarmos condições para a leitura polissêmica por meio do discurso pedagógico polêmico, observou-se que os alunos interpretam mobilizando o arquivo e as filiações ideológicas nos textos da imprensa de modo a desfazer sua aparente neutralidade.

Palavras-chave: Ensino de línguas. Discurso polêmico. Paráfrase. Polissemia.

Abstract: This article addresses the issue of a theoretical-practical research applied in Youth and Adult Education on the subject of military dictatorship in the media discourse. In this paper, the reading practice developed in the classroom is analyzed from the theoretical perspective of Discourse Analysis, observing the meaning movements in the student's gestures of interpretation from the concepts of paraphrase and polysemy. By creating conditions for the polysemic reading through the controversial pedagogical discourse, it was observed that the students interpreted mobilizing the archive and the ideological affiliations in the texts of the press in order to undo its seeming neutrality.

Keywords: Language teaching. Controversial discourse. Paraphrase. Polysemy.

Résumé: Cet article traite d'une recherche théorique-pratique appliquée à l'éducation des jeunes et des adultes sur le thème de la dictature militaire dans le discours médiatique. Dans ce travail, nous analysons la pratique de lecture développée en classe à partir de la perspective théorique de l'analyse du discours, en observant les mouvements de sens dans les gestes d'interprétation de l'élève à partir des concepts de paraphrase et de polysémie. Lorsque nous avons créé les conditions pour la lecture polysémique du discours pédagogique controversé, il a été observé que les étudiants ont interprété la

\footnotetext{
${ }^{1}$ Mestre em Ensino de Línguas pela Universidade Federal do Pampa, professor da educação básica de literatura e língua portuguesa da rede estadual do RS.

2 Doutora em Letras pela Universidade Federal do Rio Grande do Sul, docente do curso de Letras da Universidade Federal do Pampa e do Mestrado profissional em ensino de línguas da mesma universidade. Líder do grupo de pesquisa CNPq Estudos Pecheutianos.
} 
mobilisation des archives et les affiliations idéologiques dans les textes de la presse afin de défaire son apparente neutralité.

Mots-clés: Enseignement de langue. Discours polémique. Paraphrase. Polysémie.

\section{Considerações iniciais}

Esse trabalho surgiu de uma reflexão político-pedagógica sobre o ensino de língua portuguesa durante os anos de 2014 e 2015, período em que manifestações contra corrupção e o governo Dilma trouxeram à memória discursos a favor da ditadura militar. Inquieta-nos pensar por que o repúdio às práticas de perseguição política e crimes cometidos durante o regime militar não haviam se tornado um consenso na atualidade, a tal ponto de setores da sociedade novamente saírem às ruas, pedindo uma "intervenção militar", exaltando o exército brasileiro enquanto instituição capaz de "pôr o país nos eixos", estabelecer a ordem e combater os taxados "comunistas". Por que, apesar dos acontecimentos que marcaram nossa nebulosa história, documentados nas bibliografias, nos filmes, nos relatórios da Comissão Nacional da Verdade, tudo pode estar a ponto de se repetir outra vez? Nesta conjuntura, faz-se necessário pensar como o professor de língua portuguesa, em suas aulas de práticas de leitura, pode contribuir para mobilizar esses arquivos e fazer trabalhar a memória discursiva no seu aspecto polissêmico, mostrando a tensão política entre sentidos antagônicos, a fim de levar o sujeito-aluno à reflexão do modo como a imprensa dissimula sua parcialidade.

Percebemos que as aulas de linguagem nos moldes tradicionais pouco fazem o aluno refletir sobre a língua como prática discursiva e seu papel de agente social. É preciso, portanto, assumir uma nova posição-sujeito no ensino de língua portuguesa para que os alunos sejam levados a perceber a opacidade da linguagem, os diferentes discursos e a ideologia materializada no dizer. Em outras palavras, é preciso trazer a "política" para dentro da sala de aula, e, por assim dizer, "dissecá-la”. Ou seja, trabalhar em uma perspectiva discursiva, em que a língua como materialidade ideológica tenha seu lugar, e não apenas as meras análises sintáticas ou as questões de interpretação textual de múltipla escolha que, para o sujeito, nada reflete, só deixam alternativas de A a E. 
Realizou-se, então, uma pesquisa aplicada à Educação de Jovens e Adultos (AMARAL, 2015), partindo do tema da ditadura militar no discurso da mídia impressa da época, em que seria possível discutir a temática da filiação ideológica de certos órgãos de imprensa à ideologia de direita, que mobiliza os sentidos de legitimação da ditadura militar. Para isso, foi utilizado o aporte teórico da Análise de Discurso de linha francesa que nos possibilitou analisar os diferentes gestos de interpretação e mobilizar a memória discursiva para compreendermos os efeitos de sentidos que produzem o imaginário de "bons tempos" reproduzido na atualidade.

\section{A língua para a Análise do Discurso}

A Análise de discurso de linha francesa (doravante AD) relaciona linguagem e ideologia de modo constitutivo, não sendo possível, portanto, pensar o discurso e o sujeito separados da instância ideológica. Para Pêcheux (2010), pensar a noção de sujeito significa reconhecer a sua afetação por duas instâncias: o inconsciente e a ideologia. Já não se tem aqui, pois, uma noção iluminista ou cartesiana do indivíduo, como autônomo e dono de todos os seus dizeres. Essa seria apenas mais uma forma-sujeito dentro da história (ORLANDI, 2010), matriz do sujeito da sociedade de mercado. Na verdade, o sujeito é interpelado sob a aparência de estar aderindo livremente a determinadas formações ideológicas, como se pudesse estar "dentro" e "fora" da interpelação quando quisesse.

Para Orlandi (2010), a Forma Sujeito Histórica compreende um sujeito ao mesmo tempo livre e submisso, pois ele poderá dizer tudo, desde que esteja subordinado à língua para dizê-lo. E uma vez que não se trata de uma entidade ahistórica, a exterioridade o determina também, pois afeta a sua relação com os sentidos. Se na Idade Média, por exemplo, tínhamos uma Forma Sujeito subordinada à religião, no capitalismo há uma diferença: o sujeito acredita-se livre em suas escolhas, mas situa-se dentro de um Estado de direito, próprio do sistema, que organiza seus ditos. Então: 
Submetendo o sujeito, mas ao mesmo tempo apresentando-o como livre e responsável, o assujeitamento se faz de modo a que o discurso apareça como instrumento (límpido) do pensamento e um reflexo (justo) da realidade. Na transparência da linguagem, é a ideologia que fornece as evidências que apagam o caráter material do sentido e do sujeito (ORLANDI, 2010, p. 51).

Tem-se, portanto, o trabalho da ideologia, produzindo o efeito da ilusão de liberdade do sujeito, colocando-o como o senhor da sua vontade, porém, trata-se de um sujeito submisso às leis e contratos da sociedade em que vive, afetado pelas suas relações sociais e econômicas.

A ideologia é compreendida aqui, não no sentido de mascaramento ou ocultação da realidade, mas como uma instância produtora de evidências. Ela constrói o efeito do óbvio, ou conforme Pêcheux (2010, p. 46):

é a ideologia que, através do "hábito" e do "uso", está designando, ao mesmo tempo, o que é e o que deve ser, e isso, às vezes, por meio de "desvios" linguisticamente marcados entre a constatação e a norma e que funcionam como um dispositivo de "retomada do jogo". É a ideologia que fornece as evidências pelas quais "todo mundo sabe" o que é um soldado, um operário, um patrão, uma fábrica, uma greve etc., evidências que fazem com que uma palavra ou enunciado "queiram dizer o que realmente dizem" e que mascaram, assim, sob a "transparência da linguagem", aquilo que chamaremos o caráter material do sentido das palavras e dos enunciados.

Dessa forma, a ideologia é o que mobiliza os sentidos sedimentados em sociedade, dando ao sujeito a ideia de fixidez, de um estar-sempre-lá, furtando a ele a compreensão das condições de produção dos sentidos. Como exemplo disso, durante a ditadura militar brasileira, de 1964, a mídia impressa utilizava a materialidade "revolução" para referir-se ao golpe militar, e através da saturação desses sentidos produzia o efeito de obviedade a respeito do fato em questão, ou seja, de que se estava vivendo um momento positivo em nossa história. A partir desse ponto, podemos pensar a noção de língua e de discurso dentro da AD. Há uma relação necessária entre língua-discurso-ideologia, de maneira que pensarmos a língua, dentro de uma perspectiva discursiva, acarreta pensarmos ela como uma realização material do discurso. 
A noção de língua na $\mathrm{AD}$ parte do pressuposto de que ela não se reduz a um mero instrumento, sendo, pois, estudada como algo fechado, como era estudada, por exemplo, pelas gramáticas normativas. Busca-se aqui compreender a língua fazendo sentido (ORLANDI, 2010, p. 15), ou seja, enquanto parte do trabalho simbólico, que constitui o sujeito e a sua história. É preciso, portanto, considerar a exterioridade.

Conforme Orlandi (2010, p. 15-16):

Assim, a primeira coisa a se observar é que a Análise de Discurso não trabalha com a língua enquanto um sistema abstrato, mas com a língua no mundo, com maneiras de significar, com homens falando, considerando a produção de sentidos enquanto parte de suas vidas, seja enquanto sujeitos seja enquanto membros de uma determinada forma de sociedade.

Assim sendo, relacionando a linguagem à sua exterioridade, pode-se compreender a língua no seio de condições de produção, com a vida social, com os conflitos de classes, etc. Em outras palavras, a AD considera "as condições de produção constitutivas da linguagem, pela análise da relação estabelecida pela língua com os sujeitos que a falam” (ORLANDI, 2010, p. 16). Assim, a historicidade, apagada no contexto das gramáticas normativas, por exemplo, surge como uma questão importante na compreensão dos enunciados, pois trata justamente dos sentidos determinados historicamente.

Portanto, para a noção de língua na $\mathrm{AD}$, importam a exterioridade, as condições de produção dos sentidos e a ideologia. Assim sendo, não temos uma concepção de língua "adâmica", no sentido de que as palavras "nascem" com os sentidos colados a elas. Falamos aqui de opacidade e não de transparência. A língua é uma nebulosa e não um artefato de cristal, através do qual se pode observar o mundo tal como é.

A língua, pois, é a forma de existência material do discurso, que, por sua vez, é a realização material da ideologia. Se ainda é muito comum à escola utilizar-se de metodologias de ensino da língua abstrata e da leitura literal, que não ultrapassa a superfície dos textos, nos cabe, em contrapartida, refletir sobre a 
noção de leitura dentro da $\mathrm{AD}$, a fim de perceber sua contribuição teórica para novos gestos de ensino.

\section{A perspectiva discursiva da leitura}

Orlandi (2012) concebe a leitura enquanto produção de sentidos desvinculada da ideia de desvendar o pensamento do autor. A leitura na AD é vista dentro de um processo de instauração de sentidos entre o autor, o texto e o leitor, assim considera que há múltiplos gestos de leitura, de maneira que um texto é sempre heterogêneo e mantém relações com outros textos e ditos anteriores, sendo passível de análise, pois suas marcas não são autoevidentes (ORLANDI, 2012, p. 8).

De acordo com a autora, há em um texto um leitor virtual, ou seja, uma formação imaginária de leitor criada pelo autor enquanto forma ideal de leitor para aquele texto. Sendo imaginário, pode ser "cúmplice" ou "adversário" do autor. Portanto, durante a leitura, o leitor real encontra no texto o lugar do leitor virtual, podendo ocupar esse lugar ou até mesmo ter com ele uma relação de confronto. Portanto:

O leitor não interage com o texto (relação sujeito/objeto), mas com outro (s) sujeito (s) (leitor virtual, autor etc.). A relação, como diria A. Schaff (em sua crítica ao fetichismo sígnico (1966), sempre se dá entre homens, são relações sociais; eu acrescentaria históricas, ainda que (ou porque) mediadas por objetos (como o texto). Ficar na "objetividade" do texto, no entanto, é fixar-se na mediação, absolutizando-a, perdendo a historicidade dele, logo, sua significância (ORLANDI, 2012, p. 10-11).

Portanto, que pesem as proximidades, ninguém faz a leitura de um texto da mesma maneira. E assim como não podemos ter um leitor onisciente, detentor de todos os sentidos possíveis de um texto, também não temos um autor que possa controlar todos os sentidos e leituras de seu texto. Assim, compreender um texto requer saber que ele se constitui de incompletude, de implícitos. Para Orlandi (2012, p.13): "saber ler é saber o que o texto diz e o que ele não diz, mas o constitui significativamente”. Dessa forma, podem-se pensar também as relações 
de força, como quem produz o texto, com que imaginário trabalha, para quem produz, que leitura almeja para a sua produção entre outros.

Dessa forma, abordamos as noções de paráfrase e polissemia, que tratam da tensão entre a manutenção de um mesmo sentido, muitas vezes, centralizado, e a possibilidade de novas leituras. Para Orlandi (2001, p. 36):

\begin{abstract}
Essas são duas forças que trabalham continuamente o dizer, de tal modo que todo o discurso se faz nessa tensão: entre o mesmo e o diferente. Se toda vez que falamos, ao tomar a palavra, produzimos uma mexida na rede de filiação dos sentidos, no entanto, falamos com palavras já ditas. E é nesse jogo entre paráfrase e polissemia, entre o mesmo e o diferente, entre o já dito e o a se dizer que os sujeitos e os sentidos se movimentam, fazem seus percursos, (se) significam.
\end{abstract}

Compreende-se paráfrase na $\mathrm{AD}$ como a manutenção dos sentidos sedimentados, está do lado da estabilização: “os processos parafrásticos são aqueles pelos quais em todo o dizer há sempre algo que se mantém" (ORLANDI, 2001, p. 36). Assim, uma leitura meramente parafrástica passa pelo reconhecimento de um sentido que se julga ser o do texto, ou, dizendo de outra forma, o sentido que se crê dado pelo autor, porque não temos de fato acesso ao discurso do autor senão pelas marcas ou pistas deixadas no texto.

Assim, os apoiadores da ditadura militar brasileira leriam "revolução" no texto midiático de uma maneira positiva, próxima aos sentidos mobilizados pela direita política. Estando assujeitados à determinada formação discursiva, o sentido "revolução" aparece-lhes evidente, transparente e impossível de ser outro.

Se pensarmos, contudo, em outro tipo de leitura, a polissêmica, veremos que a dissensão aqui é que se torna importante, pois se trata de uma atribuição de novos sentidos ao que foi lido, rompendo com os sentidos dominantes. Utilizando o mesmo exemplo da palavra "revolução", a produção da leitura na formação discursiva dita de esquerda seria diferente. $O$ sentido de golpe militar, provavelmente, tomaria a frente, tornando-se este o sentido único possível. Assim sendo, a polissemia "se define pela atribuição de múltiplos sentidos ao texto" (ORLANDI, 2012, p. 14), possibilitando desvios e contrastes quando mobilizada em sala de aula. 
Pode-se dizer, então, que a leitura é o momento crítico da produção de sentido do texto. E nesse caso, podemos pensar como se dão as relações entre o sujeito-professor e o sujeito-aluno nas aulas de leitura na educação básica.

\section{Análise de Discurso e Ensino}

Precisamos refletir sobre o autoritarismo na aula de leitura, em que o sujeito-professor, proprietário único da fala, em um espaço que pode ir de cinquenta minutos a uma hora e quarenta, tem o poder quase irrenunciável da fala. Os alunos leem mecanicamente, interpretam segundo o que o professor espera deles, e este decide o que está certo e o que está errado quanto à leitura, de acordo com seu gesto de interpretação legitimado.

Entende-se que o controle absoluto por parte do sujeito-professor é contraproducente à aprendizagem da língua por meio da leitura, pois desconsidera o fato de que o sujeito produz a sua leitura, ele interpreta como sujeito-interpretante que é. O docente, na posição de detentor do saber, busca estancar essa fenda por onde jorram leituras e sentidos outros, para que nada saia do seu controle como se o mesmo o obtivesse (FERNANDES, 2017), pois pode ser "perigoso" tocar em certos assuntos ou pode escapar às diretrizes institucionais ou nacionais. Então, censura as posições tomadas pelos alunos através de um gesto pedagógico autoritário que privilegia a leitura parafrástica.

Para Orlandi (2012), não existe um grau zero da leitura onde o aluno se situaria, tampouco um grau dez, onde estaria o professor. O aluno já tem instalado um processo de aprendizagem, não estando, portanto, "vazio", assim como o professor não está pronto enquanto leitor. Não se trata de um processo finito. Por outro lado, se pensarmos em leituras totalmente espontâneas, vamos entrar no mito de que todas as leituras são, por assim dizer, válidas, como se não houvessem sido determinadas. Se não é questão de tudo ou nada, que procedimento de leitura adotar, então?

Quanto ao seu funcionamento, segundo Orlandi (1996), o discurso pedagógico pode assumir três formas: o discurso lúdico, o discurso polêmico e o 
discurso autoritário. O discurso lúdico, considerando-se as relações entre os interlocutores, é constituído de uma polissemia aberta, ou seja, de possibilidade de atribuição de novos sentidos sem direcionamento ou controle por parte do professor. Já no discurso polêmico, temos uma polissemia controlada, em que se abre espaço para diferentes sentidos possíveis. Os interlocutores buscam dar uma direção ao referente. Assumem, dessa forma, suas posições. E no discurso autoritário se tem o controle total do referente, com um sujeito decidindo qual o sentido. Não há necessariamente interlocutores, mas um agente exclusivo. $\mathrm{O}$ discurso autoritário, dentro das paredes da escola, acaba refletindo as relações desiguais que temos na existência social, em que a alguns é dado o direito de decidir, como ocorreu mais fortemente no regime militar, e a outros, o direito de permanecer calados. E certamente para uma prática pedagógica que se queira voltada para os direitos e a defesa dos oprimidos, não deveria estar de alguma forma imbuída de um discurso autoritário, que apagasse do cotidiano da sala de aula os sentidos que os alunos trazem do interdiscurso. A escola teria de superar, portanto, o que Pêcheux (1994) designa por “divisão social do trabalho de leitura”, em que a uns é dado o trabalho de produzir as leituras autorizadas e a outros o trabalho de simplesmente reproduzi-las.

Em uma perspectiva autoritária é que surgem projetos de lei como o "Escola sem partido", que busca inibir professores a produzir certos discursos em sala de aula, considerando-os partidários no sentido de "ideológicos". Neste projeto, vemos disseminado o discurso de ódio de conservadores aos educadores que promovem a reflexão sobre a sociedade em sala de aula, e esse discurso encontra cada vez mais ecos na sociedade. A reprodução desses discursos de ódio produz um imaginário sobre a educação de que as vozes precisam ser caladas, disciplinadas, e que professores, principalmente, são sujeitos perigosos e aliciadores, em suas palavras: "marxistas", que se aproveitam da "audiência cativa” de seus alunos para doutriná-los no marxismo. Utilizam a palavra “ideologia” em um sentido estritamente negativo, atribuindo aos professores a pecha de

3 Disponível em: https://www25.senado.leg.br/web/atividade/materias/-/materia/125666> Acesso em 10/07/2018. 
"marxistas" e "doutrinadores", defendendo um imaginário de "neutralidade" como princípio educativo (PENNA, 2016).

Trata-se de uma abordagem dentro de uma formação discursiva específica, que aqui vamos chamar de Formação Discursiva Dominante (FDD), visto que parte de uma ideologia de dominação dos sujeitos, remanescente da ditadura militar. Além disso, a FDD regula os ditos em consonância com a formação ideológica capitalista, que é a dominante em nossa sociedade, para a qual os sujeitos são força de trabalho para a produção de riqueza e seu acúmulo pelo proprietário do capital. Por isso, não interessa à escola pretendida pela FDD formar cidadãos críticos que questionem a ordem estabelecida; sua prioridade é formar mão de obra para manter a produtividade capitalista. Sendo assim, práticas mecânicas de ensino são mais desejáveis por parecerem apolíticas e condicionarem os sujeitos à repetição e obediência às normas.

No caso da "Escola sem partido", produz-se o discurso de um ensino neutro, em que os sujeitos seriam capazes de furtar-se da ideologia. Também segue ditames internacionais como os do Banco Mundial, que numa visão tecnicista, acredita e sugere que os professores não sejam formados, mas "treinados" para executarem suas tarefas (ALTMANN, 2002). Torna-se, pois, imperativo analisar o papel do professor enquanto autor de sua prática.

Se para Althusser (1980) a escola compõe os Aparelhos Ideológicos do Estado, ajustando os sujeitos à determinada ordem social, a fim de que contribuam para o bom andamento do sistema político, uma escola apartada da influência e do suporte do Estado ainda assim estaria sujeita a determinações de formações ideológicas. E como não vivemos em um mundo suprassensível, em que a realidade verdadeira esteja em um "mundo das ideias" como a visão platônica indica, entendemos que nossa realidade é marcada por condições materiais de existência as quais apreendemos através de uma relação ideológica estabelecida entre o sujeito e os acontecimentos ou objetos do mundo.

Há de se pensar, então, o sujeito-professor como um trabalhador assalariado, que vende o seu trabalho, de tal forma inserido nessa sociedade. Os Aparelhos Ideológicos do Estado (AIEs) o querem como um sujeito operacionalizado, fazedor de tarefas, seguidor de cartilhas ou - utilizando uma 
metáfora de Bauman (2010) sobre o intelectual - "aquele que molda o jardim", reproduzindo a ideologia da classe dominante.

Contudo, visualizando um espaço de resistência, pode-se ter um sujeitoprofessor autor de sua prática pedagógica, no sentido de que se desidentifica com uma pedagogia autoritária, que o torna o organizador e fiscal a serviço dos AIEs. O professor enquanto autor se assemelha mais com aqueles que não estão, por assim dizer, totalmente "assujeitados" pela ideologia dominante, ou, de acordo com Bauman (2010, p. 76), são como "bolsões potenciais de resistência”. Quando esperam dele uma certeza, ele traz uma dúvida, quando esperam um “sim”, ele dá um "talvez”. Quando esperam uma fala, ele oferece um silêncio constrangedor. Assim como um cínico de Foucault (2010) que em vez de falar ao poder, fala sobre o poder. Quer-se dizer com isso que ele não precisa estar onde o poder espera que ele esteja (ele não "se põe no seu lugar").

Urge que o sujeito-professor se compreenda não mais como cumpridor de tarefas, mas sim como especialista na sua área, aquele que pensa junto, que analisa. Para que serviria, do contrário, ter conhecimentos necessários para analisar a linguagem em sociedade? Esse professor se utiliza do discurso pedagógico polêmico, dá voz aos sujeitos-alunos, mas também confronta os discursos, apresenta um outro modo de ver, questiona o estabilizado.

E no trabalho com a leitura em sala de aula, na perspectiva discursiva, sem colocar-se com um discurso autoritário ou doutrinador, o sujeito-professor pode enveredar pelo discurso polêmico, que:

mantém a presença de seu objeto, sendo que os participantes não se expõem, mas ao contrário procuram dominar o seu referente, dandolhe uma direção, indicando perspectivas particularizantes pelas quais se o olha e se o diz, que resulta na polissemia controlada. (ORLANDI, 1996, p 15).

Dessa forma, a proposta da autora é fazer o discurso pedagógico escolar funcionar como predominantemente polêmico no sentido em que os alunos produzem seus gestos de leitura dentro de uma polissemia controlada ou administrada pelo professor, como veremos na prática analisada a seguir. 


\section{Análise dos gestos de leitura praticados em aula}

A prática de leitura analisada ocorreu em uma turma da Educação de Jovens e Adultos de uma escola estadual do município de Alegrete-RS. Os alunos possuíam perfis bem heterogêneos, iam desde desempregados a trabalhadores formais e informais, com idades entre dezenove e cinquenta anos aproximadamente. Tratava-se de um trabalho de leitura de notícias do período do regime militar retiradas da revista "O Cruzeiro" e do jornal local "Gazeta de Alegrete".

Na primeira aula, foi apresentado um texto da revista em questão sobre Luiz Carlos Prestes. O professor não entrou em questões históricas, apenas deixou fluir o que seria a leitura espontânea dos alunos, compreendendo-a como importante nesta primeira parte do trabalho. O texto, ao qual eles tiveram acesso através de um projetor, trazia a seguinte manchete: "PRESTES, o revolucionário transviado foi organizador direto da intentona" (NASSER, 1964). Essa aula foi gravada em vídeo (AMARAL, 2015), e os alunos expuseram seus gestos de leitura, alguns já avançando para além de uma leitura meramente parafrástica.

Vejamos algumas sequências discursivas (SD) das leituras produzidas em aula:

SD o1:

"transviado é o que uns anos atrás chamavam esses hippies, essa gente assim..." "Os hippies, e esses que andam nas ruas."

"É, naquela época um "transviado" era um mau exemplo."

"Um mau exemplo para a sociedade."

"Não era o mais certinho..."

Essa introdução ao assunto visou a criar condições de leitura em que os alunos percebessem os sentidos movimentados pela revista "O Cruzeiro" como alinhados à FD dominante da época, ou seja, com o discurso de apoio aos militares e à legitimação do golpe de Estado. Cazarin e Menezes (2014, p. 121) afirmam que o discurso de $O$ Cruzeiro: 
resulta de uma memória discursiva na qual o mundo estaria dividido em dois extremos - de um lado o capitalismo (sistema político considerado ideal) e, de outro, o comunismo (considerado antidemocrático e, portanto, prejudicial).

Assim, ao se filiar à FDD, o grupo jornalístico O Cruzeiro assume uma linha editorial anticomunista, que ataca opositores ao sistema capitalista bem como aos contestadores do regime ditatorial que teria livrado o país do mal do comunismo.

Os gestos de leitura em SD o1 aproximam-se aos sentidos movimentados pela revista, embora não em profundidade com relação ao contexto da época do regime, mas apontam para uma mesma direção, configurando uma leitura no sentido parafrástico. Como se percebe no gesto de leitura do aluno, dizendo que Prestes "não era o mais certinho". A FDD na qual se inscreve o discurso da revista mobiliza os sentidos de que o outro, o oponente da ditadura, é o inimigo da pátria, o mau, o perigoso. Nesse caso, o militante comunista Luiz Carlos Prestes figura no imaginário trabalhado pela revista como um "transviado", um "mau exemplo" como leem os alunos.

Ainda assim, houve determinado gesto de interpretação que mobilizou outros sentidos, como se pode ver na seguinte SD que reproduz a fala de uma aluna:

SD 02:

"Que ele era desviado, digamos, da direita, o certo [faz um movimento com o punho fechado, no sentido de que era algo como que arraigado], para fazer a revolução."

Nesta SD 02, percebemos que a aluna reconhece o discurso da revista como inscrito em uma FDD, dizendo ser Prestes “desviado" mas da direita (política). Ela envereda por uma leitura polissêmica, pois ultrapassa a superfície textual, observando a formação ideológica ali materializada. O gesto que a aluna fez com a mão, o "punho cerrado", produz o efeito de agressividade, austeridade, o que indica uma posição-sujeito de oposição ao discurso do regime militar, mostrando que se tratava de uma ideologia autoritária e violenta. Ela percebe que 
o "transviado" era desviado de uma certa ordem discursiva, movimentando-se, portanto, para além do sentido "literal".

A figura de Luiz Carlos Prestes está, por assim dizer, colada às formações imaginárias sobre o comunismo, a respeito do qual os discursos mobilizam arquivos e memórias sobre a "demonização" do comunismo. Courtine (2014, p. 134) reflete sobre a origem do discurso anticomunista na Igreja Católica, que trata essa ideologia como um "mal", algo "funesto", destruidor do "direito natural", e afirma que isso remonta desde as encíclicas papais de 1846. Conforme o autor:

É no próprio princípio dessas "doutrinas funestas", na luta de classes, que se situa a aberração. Em uma concepção organicista da sociedade como "corpo social", em que as classes sociais (as "ricas" e as "pobres") participam da harmonia do todo, tal como se completam os membros do corpo humano, a luta de classes é concebida como o mal fundamental. (COURTINE, 2014, p.134).

Assim, podemos situar que a produção de um discurso contra o comunismo, nesse momento citado, remonta a uma determinada manutenção do poder de classe, em que cada uma tem uma importância para o todo social, de modo que as transformações advindas da luta de classe são compreendidas como "aberrações", pois subvertem a coesão do "corpo social” e os sentidos logicamente estabilizados, por isso dizer "transviado" para aquele sujeito que resiste à ideologia dominante. E essa memória discursiva vai sendo sujeita a atualizações, a paráfrases discursivas, que modificam o modo de enunciar o anticomunismo, mas não deixam seu efeito negativo como apresenta o Programa Escola sem Partido.

No âmbito do Brasil, se tomarmos o trabalho de Mariani (1998), o discurso a respeito dos comunistas produziu sentidos que os colocava como "inimigos" do país no imaginário dos jornais. E a imprensa na época do regime militar não procedeu de maneira diferente, utilizando a imagem do comunista como um terrorista, procurou parafrasear esses sentidos, a fim de atingir o objetivo de legitimar a ordem repressiva e as perseguições políticas. É o que ocorreu, por exemplo, com a elevação de Carlos Marighella a grande "inimigo" a ser combatido e, uma vez morto, ser usado como símbolo do triunfo do "bem" sobre o "mal". Considerando Mariani (1998, p. 227): 
No vocabulário político brasileiro, colocado em circulação na enunciação jornalística, as denominações comunismo/comunista instauram uma ilusória estabilidade de sentidos e uma não menos ilusória literalidade. A estabilidade referencial, instituindo discursivamente o comunismo como lugar do inimigo, silenciou a possibilidade de outros sentidos; apagou, enfim, a possibilidade da discussão política no discurso jornalístico [grifos da autora].

Dessa forma, com a possibilidade de outros sentidos silenciada, falar em comunismo é evocar uma memória que o coloca como “inimigo da pátria”. Contudo trazer essa formação imaginária, na aula, a partir de um discurso pedagógico polêmico, vai possibilitando a emergência de outros sentidos.

Logo depois, aos alunos, foi apresentada uma capa da revista "O Cruzeiro" (1964) em que aparece o ex-governador de Minas Gerais Magalhães Pinto, e a inscrição: "Edição Histórica da Revolução" (AMARAL, 2015, p. 108). É ainda o contexto histórico da ditadura, e a revista faz a propaganda do golpe militar. Os gestos de leitura dos alunos acerca da manchete são expressos nas SDs a seguir:

\section{SD 03:}

"Histórica... que seria boa para a população"

"Histórica' quer dizer que... que nem do Impeachment do Collor aquela vez, que foi histórica, que conseguiram tirar ele da presidência."

"Que a revolução foi positiva, né"

"Foi um avanço"

"Que entrou para a história"

Note-se, entretanto, que os alunos, não sabendo ao certo de que "revolução" se tratava, realizando a leitura parafrástica, inscrevem seu gesto próximo aos sentidos positivos que a FDD da revista tenta mobilizar. Se o professor tivesse resumido a aula a esse tipo de leitura somente estaria praticando um discurso pedagógico autoritário que não deixa margens à polissemia e não cria condições de leitura propícias a ela. Isso pode ser silenciador ao adequar leituras a um discurso vigente.

Ao serem instigados a refletir sobre qual contexto histórico está permeando o discurso da revista, vão surgindo gestos de leitura que evocam o período da ditadura militar, e começam a perceber o fato de que a mídia se filia a determinada formação discursiva, no caso em questão à FDD. Alguns alunos 
começaram a acessar seu arquivo e retomaram o discurso sobre Prestes para realizar um novo gesto de leitura. Lembram, inclusive, do acontecimento chamado de Intentona Comunista como é o caso da seguinte SD:

SD 04:

"O que é a intentona [comunista]?"

"[Professor] A intentona foi uma revolta, que buscou o poder, lá na década de zo, e queria fazer reformas, não ia romper com o sistema, mas ia fazer reformas, lutava contra a opressão do governo."

Note-se que houve uma relação do nome de Prestes à Intentona Comunista, evento presente no arquivo do aluno. O professor responde à pergunta, a partir de seu conhecimento e sua interpretação a partir de uma FD de resistência à ideologia dominante ${ }^{4}$. E em seguida, os alunos começam a questionar o papel da imprensa, conforme as SD seguintes:

SD 05:

"Aí é que tá, a mídia vende a ideia que ela quer."

"[Professor] Isso, é nesse ponto que a gente vai buscar chegar, que a mídia vai tomar partido de alguém, principalmente quando ela aparenta não estar tomando partido de ninguém".

"Defende sempre, de preferência, o partido do lado da situação, né".

"Gosta de tirar vantagem."

Nesse momento, os alunos mobilizam em seu gesto de leitura um deslizamento dos sentidos sedimentados pela revista. Observando o processo de produção dos sentidos, eles compreendem que a imprensa produz sentidos com um interesse específico; não havendo, portanto, imparcialidade. O professor, enquanto autor, enuncia de certa posição, dizendo que a mídia "toma partido". Ele dá uma direção aos sentidos, controlando, neste momento, a polissemia. Ainda assim, o discurso pedagógico funciona como polêmico, porque direciona os gestos de leitura para um rumo oposto ao da leitura literal sem impor uma única leitura como a possível. É o que se pode perceber com a SD o6:

\footnotetext{
${ }^{4}$ É importante ressaltar que, como sujeito ideológico e afetado pelo inconsciente, por mais que o professor busque não explicitar sua posição política, acabará produzindo gestos de interpretação que apontam para certas direções e não para outras. O que o discurso polêmico busca é não impor a leitura do professor como a única possível.
} 
"O Prestes seria um grande revolucionário?"

"[Professor] Para uma outra ideologia, sim, para a revista O Cruzeiro, não. Ali para os movimentos que surgiram na ditadura, MR8, ALN, os partidos de esquerda, ele seria um grande revolucionário, no caso. Justamente por isso que para a revista O Cruzeiro..."

"Para ela, ele seria um grande "bagunçador".

Importa frisar que o aluno reconhece o professor como intérprete autorizado, tanto que faz uma pergunta para ele, embora, no final, o aluno faça a sua leitura, até mesmo interrompendo a fala do professor, ao dizer que, para a revista, Luiz Carlos Prestes seria "um grande bagunçador", aquele que "bagunça” a ordem estabelecida, ou seja, “desarruma” a casa, o que também soa diferente de dizer "perturba" a ordem ou a subverte.

O professor, enquanto pesquisador, faz a contextualização sobre o imaginário a respeito do personagem histórico em questão, dizendo quais partidos e movimentos respeitavam a figura do político comunista, e quais o tinham como bandido, mantendo a polissemia em torno da figura do revolucionário. No entanto, mesmo sem ser de modo explícito, o professor acaba direcionando a leitura dos alunos a partir do modo como mobiliza o arquivo ${ }^{5}$ sobre esse período histórico. Em aula posterior a essa, foi exibido à turma um filme sobre as perseguições aos jornalistas durante a ditadura militar, Vlado: 30 anos depois (2005), que trata dos assassinatos e torturas praticados pelos agentes repressivos do Estado, em especial contra o jornalista e militante cultural do Partido Comunista Brasileiro (PCB), Vladimir Herzog. A partir de discussões e debates sobre o período militar, os alunos foram mobilizando e atualizando seu arquivo, suas memórias familiares e de militância política.

Vejamos a SD o7:

"Então, essa ditadura militar era ruim!"

“Claro que era! E esses tempos, queriam de volta, né, com esses negócio da Dilma, né. Isso aí muita gente não aceitou, quem viveu naquela época."

"A maioria desse pessoal que pede a volta dos milicos não viveu as torturas."

"Sim, eles falam pelos outros, né."

"As pessoas que tem mais idade, agora, que viveram os anos 70, sabem como é que foi."

"Como eu disse, não é bom".

\footnotetext{
${ }^{5}$ Arquivo é definido por Pêcheux (1994, p. 57): "campo de documentos pertinentes e disponíveis sobre uma questão".
} 
Eles fazem referência a acontecimentos recentes em que grupos saíram às ruas pedindo "intervenção militar" durante protestos contra o governo Dilma Rousseff (do Partido dos Trabalhadores). Mobilizaram, em sala de aula, sentidos afetados por uma FD de oposição à FDD dos grupos de direita dos atuais protestos, que chamaremos FD de resistência (FDR).

Percebe-se também que alunos fazem referência às torturas e aos crimes cometidos pelo estado, uma vez que alimentaram seu arquivo com o filme e as discussões sobre o tema em sala de aula. Observa-se, assim, que sem utilizar um discurso pedagógico autoritário, mas sim polêmico, foi possível o professor promover o diálogo em aula de língua portuguesa, direcionando os sentidos a uma recusa às práticas da ditadura, de ataque aos direitos humanos e perseguições.

Promover o diálogo, alimentar o arquivo dos alunos, faz com que eles movimentem sentidos e memórias, como o caso da SD o8:

"Meu pai comentava que antes do golpe militar - ele sempre trabalhava, a vida toda, em lavoura - o meio de transporte na época era o trem, ele vinha pra cidade, às vezes, de trem, chegava, tava tudo em greve, não tinha como voltar, e os de lá de fora precisavam vir, os ferroviários tavam em greve. Depois que os militar deram o golpe, e assumiu o governo, ninguém mais fazia greve, até os preço foram tudo tabelado, os milico andavam com aquelas tabelinhas nos bolicho de campanha e em tudo o que era lugar, aquele que tinha o produto fora da tabela, já tinha o bolicho fechado, era preso. Não se tinha direito a nada. Justamente isso que nós tamo fazendo aqui hoje não se podia fazer".

Percebe-se nesta SD o8 que o aluno traz memórias de seu pai, constituintes de seu arquivo pessoal, o que faz com que seu discurso inscreva-se em FDs antagônicas. Em parte, é afetado pela FDD, pela qual se enunciava que o país estava em desordem, e era necessário parar o sindicalismo, como diziam do governo Jango, “república sindicalista”. E também, é afetado por uma FDR, que resiste à opressão do regime militar ao mobilizar sentidos sobre a liberdade de expressão, fazendo um paralelo entre o que estava acontecendo na aula e o que acontecia na ditadura. Alega, por exemplo, que não se tinha "direito a nada” e que a discussão que estava sendo feita em sala de aula, se feita durante a ditadura, teria sido proibida.

Essa vacilação entre uma FD e outra é possível, uma vez que o professor produzindo um discurso polêmico não impõe uma única leitura, mas oportuniza, 
assim, que o aluno vá constituindo suas filiações ideológicas a partir das redes de sentidos que produz.

Vejamos a SD o9, produzida por outro aluno:

"O Jango, ele queria o quê? Ele ia extinguir toda a época aquela que tinha a mão de obra barata, ele ia deixar mais cara, porque ia aumentar o salário, atingir os fazendeiros, porque daí eles iam ter que gastar mais. Iam ter, os pobres, os trabalhadores, direito ao estudo, porque muitos eram analfabetos, não entendiam de seus direitos, e o Jango ia proporcionar tudo isso aí. Então, o Jango, pra essa época, e esse povo da elite, não servia".

A SD o9 se inscreve em uma FDR, pois reconhece as desigualdades sociais e a prevalência do capital. Mobiliza, então, sentidos que trazem consigo uma visão mais progressista do governo Jango, valorizando os direitos do cidadão e a educação, compreendendo que é este o motivo pelo qual a elite não se agradava com o então presidente.

Em aulas subsequentes, foi solicitado aos alunos que escrevessem suas “impressões" sobre as notícias lidas em aula. Durante as produções escritas, houve um maior envolvimento dos alunos com o assunto perceptível na preocupação em refletir sobre a mídia e na crítica à ditadura militar e sua FDD, como notamos na SD 10:

"Os militares consideravam inimigos toda e qualquer pessoa que tivesse alguma simpatia pelo socialismo. O jornal Gazeta de Alegrete era um jornal que apoiava os militares mesmo antes do golpe militar. Os militares consideravam o comunismo um terror que destruiria o nosso país."

A SD 10 refere a uma notícia publicada no jornal Gazeta de Alegrete que exaltava uma operação feita pelo exército para perseguir simpatizantes do comunismo, entre eles estudantes, militares, funcionários públicos, entre outros (AMARAL, 2015, p. 139).

A escrita serviu como o registro final das aulas, momento em que os alunos perceberam que podiam ler de outra forma, valorizando a historicidade e a dimensão ideológica da linguagem. Realizaram gestos de leitura de compreensão do processo de significação empreendido pela mídia com relação à FDD. Reconheceram, portanto, que ler não estava restrito a "desvendar" o significado de palavras dado pelo texto, mas que envolve compreendê-lo dentro de condições materiais de produção do sentido. 
Para criar essas condições pedagógicas para o ensino de língua, foi importante desenvolver circunstâncias para alimentar os arquivos de leituras dos alunos e deixá-los propensos a ler e manifestar suas leituras, trazendo à pauta questões históricas e ideológicas. Tanto que, mesmo após o trabalho, percebemos que os alunos tomaram uma outra posição com relação aos modos de ler, visto que seguiam buscando sempre algo mais nos textos, como, por exemplo, nas aulas de literatura, em que se indagavam, ou indagavam o professor, sobre os implícitos, os não-ditos que reverberaram sentidos na leitura.

O papel do professor, enquanto autor de sua prática, é importante para justamente trazer subsídios às leituras dos alunos e criar as condições à polissemia. E, apesar de discursos conservadores da FDD advogarem o contrário, como os entusiastas da Escola Sem Partido, um docente calado não pode levar o aluno a assumir a posição de autor sem que ele mesmo a tenha experimentado.

\section{Conclusão}

Nosso trabalho com a perspectiva discursiva em sala de aula, na Educação de Jovens e Adultos, levou-nos a refletir sobre questões importantes no âmbito pedagógico, respondendo a inquietações surgidas por parte tanto de alunos quanto de professores, advindas, em grande medida, do fato de o país estar vivendo, na atualidade, um momento de retrocesso social. Que resposta teria a escola a dar a uma sociedade que vê pessoas saírem às ruas pedindo "intervenção militar", bradando contra o comunismo e o sindicalismo? A intervenção pedagógica é importante no sentido em que a escola como formadora de sujeitos reflexivos não pode se abster do debate. O professor, inserindo seus alunos nessa discussão, gerenciou leituras de arquivo sobre o período militar com o propósito de levá-los a compreender o modo de produção desses sentidos parafraseados na atualidade por grupos conservadores.

A promoção de uma leitura polissêmica em sala de aula, principalmente na EJA, em que as memórias são um pouco mais longevas do que em outras modalidades de ensino, criou as condições necessárias para que os alunos 
mobilizassem seu arquivo de leitura ao mesmo tempo em que ia sendo atualizado e alimentado com outros sentidos. Para isso, foi necessário ao professor rever sua postura pedagógica, assumindo sua autoria e posicionamento crítico, dentro de um discurso pedagógico polêmico, de forma que aos alunos coube produzir leituras possíveis e não restritas à reprodução de uma leitura autorizada (PÊCHEUX, 1994).

O discurso pedagógico polêmico possibilitou esse novo olhar aos alunos, pois no lugar de o professor afastar-se totalmente das leituras, ou dominá-las em absoluto, ele colocou-se enquanto autor de sua prática pedagógica, auxiliando os alunos em suas inquietações sobre os textos, mobilizando a memória discursiva juntamente com eles, criando, dessa forma, condições para uma leitura polissêmica. O sujeito-professor toma consciência, pois, de seu papel como especialista naquela área de conhecimento e se faz presente.

\section{Referências}

ALTHUSSER, L. Ideologia e aparelhos ideológicos do estado. Lisboa: Editorial Presença, 1980. Tradução de Joaquim José de Moura Ramos.

ALTMANN, H. Influências do banco mundial no projeto educacional brasileiro. Educação e Pesquisa: São Paulo, v. 28, n. 1, jan./jun. 2002, p. 77-89.

AMARAL, P. L. F. do. A ditadura militar brasileira no discurso midiático: a leitura por um viés discursivo na EJA. Bagé, RS: Unipampa, 2015. 166 f. (Dissertação) Mestrado Profissional no Ensino de Línguas - Universidade Federal do Pampa, Bagé, 2015.

BAUMAN, Z. Legisladores e intérpretes. Rio de Janeiro: Zahar, 2010. Tradução de Renato Aguiar.

BRASIL. Câmara dos deputados. Projeto de Lei no 867, de 2015. "Escola sem partido". Disponível em: <http://www.camara.gov.br/sileg/integras/1317168.pdf>. Acesso em: 15 mar. 2018. 
COURTINE, Jean-Jacques. Análise do discurso político: o discurso comunista endereçado aos cristãos. Tradução: Cristina de Campos et al. São Carlos: EDUFSCAR, 2014 .

CAZARIN, E. A.; MENEZES, E. S. de. A mídia e o golpe de 1964: revista O Cruzeiro como aliada do discurso das forças militares. Conexão Letras. A noção de arquivo em Análise do Discurso: relações e desdobramentos. Porto Alegre: Universidade Federal do Rio Grande do Sul, v. 9, n. 11, 2014, p. 111-122.

FERNANDES, C. O professor e sua ilusão de "domínio": uma análise discursiva da prática pedagógica escolar no ensino de língua portuguesa. Revista de Educação, Ciência e Cultura. Canoas, v. 22, n. 3, nov. 2017, p. 77-91.

FOUCAULT, M. O governo de si e dos outros. Tradução de Eduardo Brandão. São Paulo: Martins Fontes, 2010.

MARIANI, Bethania. O PCB e a imprensa: Os comunistas no imaginário dos jornais 1922-1989. Rio de Janeiro: Revan, 1998.

NASSER, Davi. Revista O Cruzeiro Extra. Rio de Janeiro: Diários Associados, Abril, 1964 .

ORLANDI, E. P. A linguagem e seu funcionamento: as formas do discurso. São Paulo: Pontes, 1996.

. Análise de Discurso: princípios e procedimentos. Campinas, SP: Pontes Editores, 2010.

. Discurso e Leitura. Campinas: Editora da Universidade Estadual de Campinas, 2012.

PENNA, Fernando. O ódio aos professores. In: AÇÃO EDUCATIVA ASSESSORIA, PESQUISA E INFORMAÇÃO (Org.) A ideologia do movimento Escola Sem Partido: 20 autores desmontam o discurso. São Paulo: Ação Educativa, 2016.

PÊCHEUX, M. Ler o arquivo hoje. Tradução Bethânia S. Mariani et al. In: ORLANDI, Eni et al. (Org). Gestos de leitura: da história no discurso. Campinas, SP: Editora da Unicamp, 1994, p. 55-66.

. Semântica e Discurso: uma crítica à afirmação do óbvio. Tradução

Eni Orlandi et al. Campinas: Ed. da Unicamp, 2010. 
VLADO: 30 ANOS DEPOIS. Direção e produção João Batista de Andrade. São Paulo: Oeste Filmes, 2005. Disponível em:< https://www.youtube.com/watch?v=pB8XCSwyOeU>. Acesso em: 22 mar. 2018.

\section{Recebido em 16/09/2018.}

Aprovado em 04/11/2018. 